\title{
Molecular Cloning of a Glibenclamide-sensitive, Voltage-gated Potassium Channel Expressed in Rabbit Kidney
}

\author{
Xiaoqiang Yao, Alice Y. Chang, Emile L. Boulpaep, Alan S. Segal, and Gary V. Desir \\ Departments of Internal Medicine and Cellular and Molecular Physiology, Yale University School of Medicine and West Haven Veterans \\ Administration Medical Center, New Haven, Connecticut 06510
}

\begin{abstract}
Shaker genes encode voltage-gated potassium channels $\left(\mathrm{K}_{\mathrm{v}}\right)$. We have shown previously that genes from Shaker subfamilies $K_{v 1.1}, 1.2,1.4$ are expressed in rabbit kidney. Recent functional and molecular evidence indicate that the predominant potassium conductance of the kidney medullary cell line GRB-PAP1 is composed of Shaker-like potassium channels. We now report the molecular cloning and functional expression of a new Shaker-related voltage-gated potassium channel, rabK $_{\mathrm{v} 1.3}$, that is expressed in rabbit brain and kidney medulla. The protein, predicted to be 513 amino acids long, is most closely related to the $K_{v 1.3}$ family although it differs significantly from other members of that family at the amino terminus. In Xenopus oocytes, rabK $_{\mathrm{v} 1.3}$ cRNA expresses a voltage activated $K$ current with kinetic characteristics similar to other members of the $\mathbf{K}_{\mathrm{v} 1.3}$ family. However, unlike previously described Shaker channels, it is sensitive to glibenclamide and its single channel conductance saturates. This is the first report of the functional expression of a voltage-gated $\mathrm{K}$ channel clone expressed in kidney. We conclude that rabK $_{\mathrm{v} 1.3}$ is a novel member of the Shaker superfamily that may play an important role in renal potassium transport. (J. Clin. Invest. 1996. 97:25252533.) Key words: potassium channel - molecular biology • kidney • glibenclamide $\bullet$ Shaker
\end{abstract}

\section{Introduction}

Detailed kinetic analyses of voltage-gated $\mathrm{K}\left(\mathrm{K}_{\mathrm{v}}\right)$ channels indicate that they are heterogeneous with respect to single channel conductance, threshold for activation by voltage, kinetics of inactivation, and inhibitor profiles. These channels have been studied most extensively in excitable cells where they participate in diverse cellular functions such as action potential and pacemaker activity (1). Recently it has been appreciated that $\mathrm{K}_{\mathrm{v}}$ channels play a crucial role in the regulation of vascular smooth muscle contraction and, therefore, peripheral vascular resistance and blood pressure (2-4). In contrast, there are few reports of $\mathrm{K}_{\mathrm{v}}$ currents in epithelial cells (eye and type II pneumocytes) $(5,6)$.

Until recently, $K_{v}$ channels had not been detected in renal epithelia. The primary physiological role of $K_{v}$ channels in epi-

Address correspondence to Gary V. Desir, Department of Medicine, Section of Nephrology, Yale University School of Medicine, West Haven VA Medical Center, 2073 LMP, 333 Cedar St., New Haven, CT 06510. Phone: 203-932-5711x2452; FAX: 203-937-4723; E-mail: gary.desir@QM.yale.edu

Received for publication 18 October 1995 and accepted in revised form 20 March 1996.

The Journal of Clinical Investigation

Volume 97, Number 11, June 1996, 2525-2533 thelial cells is uncertain since most $\mathrm{K}_{\mathrm{v}}$ channels have an activation threshold that is $>-50 \mathrm{mV}$ and thus would open only when the cell membrane depolarizes beyond $-50 \mathrm{mV}$. Such channels would remain closed in epithelial cells since the resting basolateral membrane potential $\left(\mathrm{V}_{\mathrm{bl}}\right)$ of these cells remains between -60 and $-90 \mathrm{mV}$ under physiological conditions. However, it is likely that renal cortical and medullary collecting duct cells undergo changes in membrane potential sufficient to activate $\mathrm{K}_{\mathrm{v}}$. Indeed, the measured intracellular potential across the apical membrane $\left(\mathrm{V}_{\mathrm{a}}\right)$ of cells in the distal part of the cortical collecting duct (CCD) ${ }^{1}$ averages about $-20 \mathrm{mV}$, within the range for $\mathrm{K}_{\mathrm{v}}$ channels to be active. Voltage and calcium-gated K (Maxi K) channels have been detected in rabbit CCD (7). These channels were initially thought to contribute significantly to $\mathrm{K}$ secretion in the distal tubule, but it appears that under physiologic conditions they open infrequently and could not account for the observed rate of $\mathrm{K}$ efflux. It is possible, however, that $\mathrm{K}_{\mathrm{v}}$ channels open in response to changes in $\mathrm{V}_{\mathrm{a}}$ that occur in CCD cells during sustained Na reabsorption.

In the inner medulla, interstitial $[\mathrm{K}]_{\mathrm{o}}$ can reach levels up to $40 \mathrm{mM}$ as a result of the well established process of $\mathrm{K}$ recycling (8). $V_{b l}$ is close to the reversal potential for $K\left(E_{K}\right)$ since $K$ channels constitute the dominant conductance of unstimulated cells. Therefore, increasing interstitial $[\mathrm{K}]_{\mathrm{o}}$ from 4 to $40 \mathrm{mM}$ will cause $\mathrm{E}_{\mathrm{K}}$ to change from -86 to $-28 \mathrm{mV}$ (assuming $[\mathrm{K}]_{\mathrm{i}}=$ $120 \mathrm{mM}$ ), depolarizing $\mathrm{V}_{\mathrm{bl}}$. This degree of depolarization would be sufficient to activate most $\mathrm{K}_{\mathrm{v}}$ channels since their threshold for activation is usually $>-50 \mathrm{mV}$.

Recently, the first functional evidence of $\mathrm{K}_{\mathrm{v}}$ expression in the renal medulla was provided by Volk et al. (9). They found that the predominant conductance in the rabbit papillary epithelial cell line GRB-PAP1 was a slowly inactivating, timeand voltage-dependent $\mathrm{K}$ current. The kinetic characteristics and inhibitor profile of this $\mathrm{K}$ channel are very similar to those of the voltage-gated $\mathrm{K}$ channel proteins belonging to the Shaker superfamily. Indeed, those authors also provided preliminary molecular evidence for expression of a member of the Shaker subfamily $\left(\mathrm{K}_{\mathrm{v} 1.2}\right)$ in these cells. In this paper, we report the identification and molecular characterization of a novel $\mathrm{K}_{\mathrm{v}}$ channel, rabK $_{\mathrm{v} 1.3}$, that is expressed in kidney medulla and in GRB-PAP1 cells.

\section{Methods}

\section{Library screening and DNA cloning}

A rabbit genomic library cloned in EMBL-3 (CLONTECH, Palo Alto, CA) was screened using $\mathrm{KC} 22\left(\mathrm{~K}_{\mathrm{v} 1.1}\right)$ a Shaker-related $\mathrm{K}$ chan-

1. Abbreviations used in this paper: 4-AP, 4 amino-pyridine; CCD, cortical collecting duct; CTX, charybdotoxin; IMCD, inner medullary collecting duct; PKC, protein kinase C; RPA, RNAase protection assay; TEA, tetra-ethyl ammonium. 
nel gene highly expressed in kidney (10). KC22 was labeled by random primer extension $\left(0.5-1 \times 10^{9} \mathrm{cpm} / \mu \mathrm{g}\right.$ DNA) with $\left[{ }^{32} \mathrm{P}\right] \mathrm{dCTP}$ (3,000 Ci/mmol; Amersham, Arlington Heights, IL). $1 \times 10^{6}$ clones were screened in duplicate at $42^{\circ} \mathrm{C}$ in buffer containing 0.5 million $\mathrm{cpm} / \mathrm{ml}$ of labeled probe, $50 \%$ formamide, $0.5 \mathrm{M} \mathrm{Na}_{2} \mathrm{HPO}_{4}, 1 \mathrm{mM}$ EDTA, $7 \%$ SDS, $1 \%$ BSA, pH 7.2. Filters were washed in $2 \times$ SSC $(300 \mathrm{mM} \mathrm{NaCl}, 30 \mathrm{mM}$ sodium citrate, $\mathrm{pH} 7$ ) and $0.5 \%$ SDS at room temperature for $1 \mathrm{~h}$ and then in $0.2 \% \mathrm{SSC} / 0.1 \%$ SDS at $42^{\circ} \mathrm{C}$ for 45 $\min$. One clone, rabK $_{\mathrm{v} 1.3}$ was preferentially expressed in rabbit medulla. It was isolated and plaque-purified and the genomic insert was cut out with SacI. Bands that hybridized to KC22 on Southern blot were cloned into pBluescript (Stratagene, San Diego, CA) and sequenced by the dideoxynucleotide chain termination method of Sanger (11). Overlapping sequence of both strands was obtained by either subcloning the appropriate restriction fragments or by using sequence specific oligonucleotides. Nucleotide and protein sequence analysis was carried out using the Genetics Computer Group software package on a VAX mainframe computer (Yale Biomedical Computer Center) and the program MacVector (Kodak, IBI). The GenBank accession number for the nucleotide sequence of $\operatorname{rabK}_{\mathrm{v} 1.3}$ is U238240. The phylogenetic tree analysis is based on amino acid sequence alignments using CLUSTALV (12) (Genetics Computer Group software package on VAX mainframe computer, Yale Biomedical Computer Center). The phylogenetic tree was reconstructed using that alignment and a PAM250 residue weight table.

\section{RNAase protection assay (RPA)}

A 308-bp fragment of the coding region of rabK $_{\mathrm{v} 1.3}$ (nucleotides 994 1302) was chosen to generate the cDNA template. Since this region has $<80 \%$ nucleotide similarity with the most closely related Shaker isoforms, it will specifically detect $\mathrm{rabK}_{\mathrm{v1} .3}$ message under the conditions used for RPA. The 308-bp fragment was amplified by PCR using the following gene-specific primers: sense TCC ATG CGG GAG CTG GGG CTG; antisense GGA TCC TAA TAC GAC TCA CTA TAG GGA GGA AGT TGC TCT T CC CCT TCG GTC TC. Since the antisense primer used contained the consensus sequence for $\mathrm{T} 7$ RNA polymerase (33 bp underlined above) the labeled antisense riboprobe was synthesized directly from PCR-amplified cDNA using T7 RNA polymerase (Promega, Madison, WI) and [ $\left.{ }^{32} \mathrm{P}\right] \mathrm{UTP}(3,000$ $\mathrm{Ci} / \mathrm{mmol}$; Amersham) (protocol provided by Promega) and was gel purified ( $5 \%$ polyacrylamide). The hybridization reaction contained 10-100 $\mu \mathrm{g}$ of total RNA (isolated from freshly dissected rabbit organs or from cultured cells) in $80 \%$ formamide, $1 \mathrm{mM} \mathrm{EDTA}, 0.4 \mathrm{M} \mathrm{NaCl}$, $40 \mathrm{mM}$ Pipes, $\mathrm{pH} 6.4$, and $2.5 \times 10^{5} \mathrm{cpm}$ of antisense riboprobe in a total volume of $30 \mu \mathrm{l}$. The reaction mixture was overlaid with $50 \mu \mathrm{l}$ of mineral oil and incubated at $50^{\circ} \mathrm{C}$ for $16 \mathrm{~h}$. The total amount of RNA in each sample was kept constant $(100 \mu \mathrm{g})$ by adding the appropriate amount of yeast tRNA. The hybridization products were digested by adding $300 \mu \mathrm{l}$ of an RNAase digestion mixture $(300 \mathrm{mM} \mathrm{NaCl}$, $10 \mathrm{mM}$ Tris, $5 \mathrm{mM}$ EDTA, $2 \mu \mathrm{g} / \mathrm{ml}$ RNAase T1, $40 \mu \mathrm{g} / \mathrm{ml}$ RNAase A, $\mathrm{pH}$ 7.4) and incubated for $1 \mathrm{~h}$ at $32^{\circ} \mathrm{C}$. The mixture was then incubated for $30 \mathrm{~min}$ at $37^{\circ} \mathrm{C}$ with proteinase $\mathrm{K}(0.03 \mathrm{mg} / \mathrm{ml})$ in the presence of $0.6 \%$ SDS. The reaction was extracted with phenol/chloroform and the RNAase-resistant products were precipitated by adding $1 \mu \mathrm{g}$ of glycogen, $750 \mu \mathrm{l}$ of ice-cold ethanol and incubating at $-70^{\circ} \mathrm{C}$ for $1 \mathrm{~h}$. The pellet was washed with $70 \%$ ethanol, dried at room temperature, and dissolved in formamide loading buffer ( $80 \%$ formamide, $10 \mathrm{mM}$ EDTA, pH $8,1 \mathrm{mg} / \mathrm{ml}$ xylene cyanol FF, $1 \mathrm{mg} / \mathrm{ml}$ bromophenol blue). The reaction products were size-fractionated by denaturing polyacrylamide (5\%) gel electrophoresis (13). HaeIII digest fragments of l-bacteriophage were end-labeled with T4 polynucleotide kinase (Boehringer Mannheim, Indianapolis, IN) and $\left[{ }^{32} \mathrm{P}\right] \gamma \mathrm{ATP}$ and used as size markers. The gel was dried and exposed to film for $48 \mathrm{~h}$ with two intensifying screens at $-50^{\circ} \mathrm{C}$. Autoradiograms were scanned by densitometry. Since the intact probe contains $\sim 20$ bp of nonhomologous sequence it was easily distinguished from a protected fragment.

\section{cDNA amplification}

Pairs of primer [sense (540-561) 5'-CGTCATCCTCATCTCCATCGTC-3', antisense (1498-1476) 5'-GGTTATTGTTCGTGGTGCAAGTG-3'] were mixed at a final concentration of $0.1 \mu \mathrm{M}$ each, with cDNA (from GRB-PAP1 cells) and $2 \mathrm{U}$ of Amplitaq DNA polymerase (Perkin-Elmer Cetus, Norwalk, CT) in a total volume of $50 \mu$ l. The final magnesium concentration was $1.5 \mathrm{mM}$. PCR was performed for 40 cycles denaturation for $1 \mathrm{~min}$ at $95^{\circ} \mathrm{C}$, annealing for $1 \mathrm{~min}$ at $50^{\circ} \mathrm{C}$, and elongation for $1 \mathrm{~min}$ at $72^{\circ} \mathrm{C}$. In the negative control, reverse transcriptase was omitted from the cDNA synthesis step. The amplified product $(20 \mu \mathrm{l})$ was size-fractionated by agarose gel electrophoresis and transferred to a nylon membrane (GeneScreen; $\mathrm{Du}$ Pont/New England Nuclear, Boston, MA). The filter was prehybridized for $2 \mathrm{~h}$ in buffer containing $60 \mathrm{mM} \mathrm{Na} 2 \mathrm{HPO}_{4} / \mathrm{NaH}_{2} \mathrm{PO}_{4}, \mathrm{pH}$ $6.8,1 \mathrm{M} \mathrm{NaCl}, 1 \%$ SDS, and $10 \%$ dextran sulfate at $42^{\circ} \mathrm{C}$, then hybridized with a ${ }^{32} \mathrm{P}$-end-labeled oligonucleotide probe (nucleotides 1014-1037 5'-GCTCATCTTCTTCCTCTTCATTGG-3') at a concentration of 0.4 million $\mathrm{cpm} / \mathrm{ml}$ (specific activity of $0.5 \times 10^{7} \mathrm{cpm} / \mu \mathrm{g}$ DNA) for $16 \mathrm{~h}$ at $42^{\circ} \mathrm{C}$. The filter was washed once in $2 \times \operatorname{SSC}(300$ $\mathrm{mM} \mathrm{NaCl}, 30 \mathrm{mM}$ sodium citrate, $\mathrm{pH} 7$ ) and $0.5 \%$ SDS for $10 \mathrm{~min}$ at room temperature and once in $1 \times \mathrm{SSC}$ and $0.5 \% \mathrm{SDS}$ at $42^{\circ} \mathrm{C}$ for 10 min. The filter was then exposed to film using intensifying screens at $-50^{\circ} \mathrm{C}$ for $4-16 \mathrm{~h}$

\section{Expression of rabK ${ }_{v 1.3}$ in Xenopus oocytes}

Oocyte preparation. Stage V-VI Xenopus laevis oocytes were dissected from ovarian lobes and stored in modified Barth's solution. The vegetal pole of selected oocytes was injected with $50 \mathrm{nl}$ containing $5 \mathrm{ng}$ of in vitro transcribed, $5^{\prime}$-capped rabK $_{\mathrm{v} 1.3}$ RNA or water as a negative control.

Electrophysiology. Whole-cell currents were recorded using a standard two-microelectrode voltage clamp. Voltage-clamped current measurements were made after a $1-3-d$ incubation period and expressed potassium currents were compared with those from waterinjected control oocytes. For voltage clamping, oocytes were impaled with two microelectrodes filled with $0.5 \mathrm{M} \mathrm{KCl}$ (resistance $0.5-5$ $\mathrm{M} \Omega$ ). Oocyte current-voltage (I-V) relationships were obtained by applying command voltage steps and measuring the resulting membrane current with a current-to-voltage amplifier (Warner Instruments Corp., Hamden, CT). The command voltage square wave was held for a duration sufficient to achieve steady state currents. Currents were filtered at $2 \mathrm{kHz}$ and the data were recorded and analyzed using Pulse-Fit (Heka, Lambretch, Germany) and Igor-Pro (WaveMetrics, Lake Oswego, OR). The bath contained (mM): $88 \mathrm{NaCl}, 2$ $\mathrm{KCl}, 1 \mathrm{CaCl}_{2}, 1 \mathrm{MgCl}_{2}, 2.5 \mathrm{NaH}_{2} \mathrm{CO}_{3}, 5$ Hepes, $\mathrm{pH}$ 7.4. For ion substitution and tail current analysis, the chloride-salt of the test cation was substituted for $\mathrm{NaCl}$. Ion selectivity was measured by tail current analysis. Pulse protocols are shown in the figures.

Single channel currents were amplified with a patch clamp amplifier (EPC-7; List Electronics, Darmstadt, Germany). Currents were filtered at $1 \mathrm{kHz}$ for analysis, and records were analyzed using software written in our laboratory (14). The bath contained (mM): 88

MIWPGDHI IDPRVRRGFGACGGGAGCDRSTPAAGEQECCGERWINISGVRFETOIKTL 60 COFPETLLGDPKRRMRYFDPLRNEYFFDRNRPSFDAПYYYOSGCRIRRPVNVDDIFSE 120 EIRFYQLGEFAMEKEREDEGFLREFDRPLPRRDFCROWTLFEYPESSGPARGIATVSVL 180 VIUISIVIFCLETI_PEFRDEKDYPAAPSQDVVAAGNGTSGAPACASSFSDPFFWEILC 240 IIWFSFELLVRFFACPSKATFSRNIMLIDIVAIIPYFITLGIEIAEROGNGOOAMSLAI 300 IRVIRLVRVFRIFKLSRHSKGLOIIGQII IASTRELGLLIFFLFIGVILFSAVYFAEAD 360 DPISGESSIPDAFWWAWIMITVGYGDMHPVTIGGKIVGSLCAIAGVLIIALPVPVIVSN 420 FNYFYHRETEGEEQAOYMHVGSCQHLSSSAEETRKARSNSTLSKSEYMVIFFGGMNHSAF 480 PQLPFKICINSTATCITINNDPNSCVNIKKIFTDV

Figure 1. Deduced amino acid sequence of rabK $\mathrm{v}_{\mathrm{v} .3 .3}$. The deduced amino acid sequence for $\operatorname{rabK}_{\mathrm{v} 1.3}(513 \mathrm{aa})$ is shown in single letter code. The single letter amino acid code is: $A$, Ala; $C$, Cys; $D$, Asp; $E$, Glu; $F$, Phe; $G$, Gly; $H$, His; $I$, Ile; $K$, Lys; $L$, Leu; $M$, Met; $N$, Asn; $P$, Pro; $Q$, Gln; $R$, Arg; $S$, Ser; $T$, Thr; $V$, Val; $W$, Trp; $Y$, Tyr. 


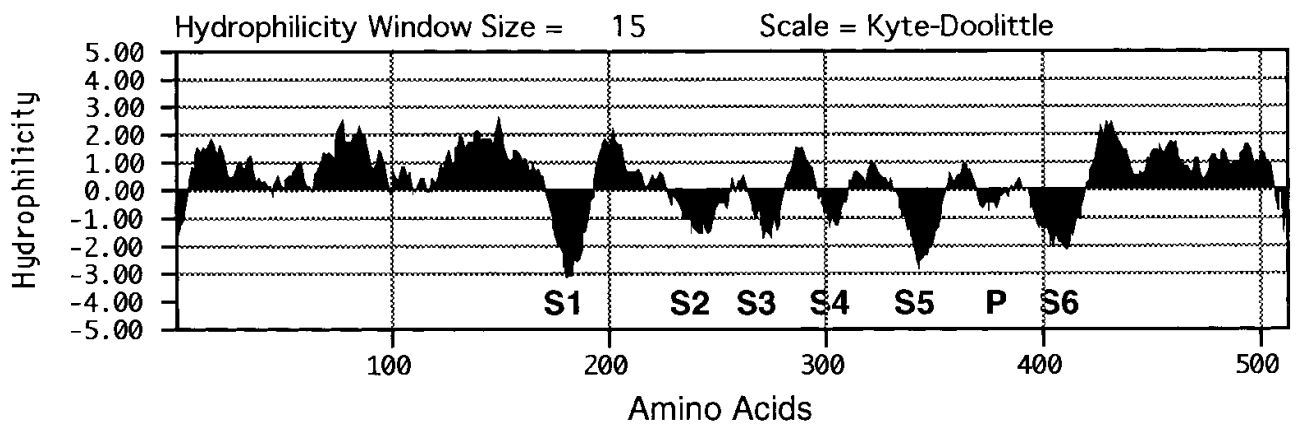

Figure 2. Hydropathy analysis of rabK $_{\mathrm{v1} .3}$. Transmembrane segments are labeled S1-S6 and P (pore region). Potential transmembrane segments were identified by analyzing (MacVector, IBI, Kodak) the deduced amino acid sequence using the KyteDoolittle.
$\mathrm{KCl}, 2 \mathrm{NaCl}, 1 \mathrm{CaCl}_{2}, 1 \mathrm{MgCl}_{2}, 2.5 \mathrm{NaH}_{2} \mathrm{CO}_{3}, 5$ Hepes, $\mathrm{pH}$ 7.4. The pipette contained (mM): $88 \mathrm{NaCl}, 2 \mathrm{KCl}, 1 \mathrm{CaCl}_{2}, 1 \mathrm{MgCl}_{2}, 2.5$ $\mathrm{NaH}_{2} \mathrm{CO}_{3}, 5$ Hepes, pH 7.4.

\section{Results and Discussion}

Molecular cloning of rabK $K_{v 1.3}$. The coding region of $\mathrm{rabK}_{\mathrm{v} 1.3}$ was identified from the genomic clone by a combination of Southern blotting and DNA sequencing. The longest open reading frame is 1539 nucleotides long and encodes a 513amino acid protein (Fig. 1). Hydropathy analysis indicates that rabK $_{\mathrm{v} 1.3}$ has six transmembrane domains, S1-S6 and a pore region (Fig. 2). Phylogenetic tree reconstruction shows that rabK $_{\mathrm{v} 1.3}$ is most closely related to the $\mathrm{K}_{\mathrm{v} 1.3}$ Shaker family (Fig. 3 ). Indeed, the transmembrane segments (S1-S6) are well conserved as are the pore region $(\mathrm{P})$ and the carboxy terminus (Fig. 4). rabK $\mathrm{v} 1.3_{3}$ contains consensus sequences for a protein kinase $\mathrm{C}$ (PKC) site between S4 and S5, a tyrosine kinase phosphorylation site at the amino terminus, and an $\mathrm{N}$-glycosylation site between S1 and S2. The PKC site between S4 and S5 is conserved among all Shaker K channels and is believed to play an important role in channel function. Phosphorylation of that site appears to downregulate channel activity (15).

The degree of overall similarity (Table I, Fig. 4) between the rabbit clone and human, mouse, and rat $\mathrm{K}_{\mathrm{v} 1.3}$ at the nucleotide and amino acid levels suggests that the gene represents rabbit $\mathrm{K}_{\mathrm{v} 1.3}$. Cloning artifacts are ruled out by the facts that the coding region is intronless and was identified from a single $12-\mathrm{kb}$ genomic library clone. However, the amino terminus of the rabbit gene diverges significantly from that of other species. In contrast to $\mathrm{K}_{\mathrm{v} 1.3}$ isolated from rat, mouse, or human, rabK $_{\mathrm{v} 1.3}$ contains two deletions ( 9 and 6 amino acids, respectively) and an 11-amino acid region (preceding the first deletion) that is different from other $\mathrm{K}_{\mathrm{v} 1.3}$ s. Sequence divergence at the amino terminus is unlikely to be accounted for by a species difference since $\mathrm{K}_{\mathrm{v} 1.3}$ isoforms from mouse, human, and rat show $>80 \%$ amino acid identity in that region. This suggests that the clone may represent a $\mathrm{K}_{\mathrm{v} 1.3}$-related gene rather than rabbit $\mathrm{K}_{\mathrm{v} 1.3}$. One would then predict the existence of another $\mathrm{K}_{\mathrm{v} 1.3}$ gene in rabbit. We currently have no data detecting two $\mathrm{K}_{\mathrm{v} 1.3}$ isoforms in rabbit and therefore we cannot exclude the possibility that the gene we cloned in rabbit represents the rabbit $\mathrm{K}_{\mathrm{v} 1.3}$. Accordingly, the clone has been named $\mathrm{rabK}_{\mathrm{v} 1.3}$. It is possible that the divergence at the amino terminus could affect channel assembly since the amino terminus is known to play an important role in homo- and heteromultimeric channel formation $(16,17)$.

The highest levels of rabK $_{\mathrm{v} 1.3}$ expression are in brain and kidney medulla (Fig. $5 A$ ). It is noteworthy that rabK $_{\mathrm{v} 1.3}$ mes- sage is also expressed in the rabbit kidney cell line GRB-PAP1 (Fig. 5 B) since Volk et al. (9) provided molecular evidence for expression of $\mathrm{K}_{\mathrm{v} 1.2}$ genes in these cells and showed that in cells grown on permeable support, the dominant membrane current is a Shaker-like delayed rectifier. These data do not exclude the possibility that in addition to $\mathrm{K}_{\mathrm{v} 1.2}$, other Shaker isoforms are also expressed in GRB-PAP1 cells. In fact, based on the inhibitor profile reported for the Shaker current detected in GRB-PAP1 cells, one would predict that the observed current cannot be mediated by homomultimers of $\mathrm{K}_{\mathrm{v} 1.2}$. Indeed, the inhibitor profiles of the current for tetra-ethyl ammonium (TEA), dendrotoxin, and charybdotoxin (CTX) do not fit those reported for homomultimers of $\mathrm{K}_{\mathrm{v} 1.2}$ (18). It is likely that the observed current in GRB-PAP1 cells is mediated by heteromultimeric channels composed of at least $\mathrm{K}_{\mathrm{v} 1.1}, \mathrm{~K}_{\mathrm{v} 1.2}$, and $\mathrm{K}_{\mathrm{v} 1.3}$. Mouse $\mathrm{K}_{\mathrm{v} 1.2}$ is $71 \%$ similar to rabbit $\mathrm{K}_{\mathrm{v} 1.3}$ at the amino acid level. These findings suggest an important physiological role for rabK $_{\mathrm{v} 1.3}$ and other Shaker-like channels in the inner medulla.

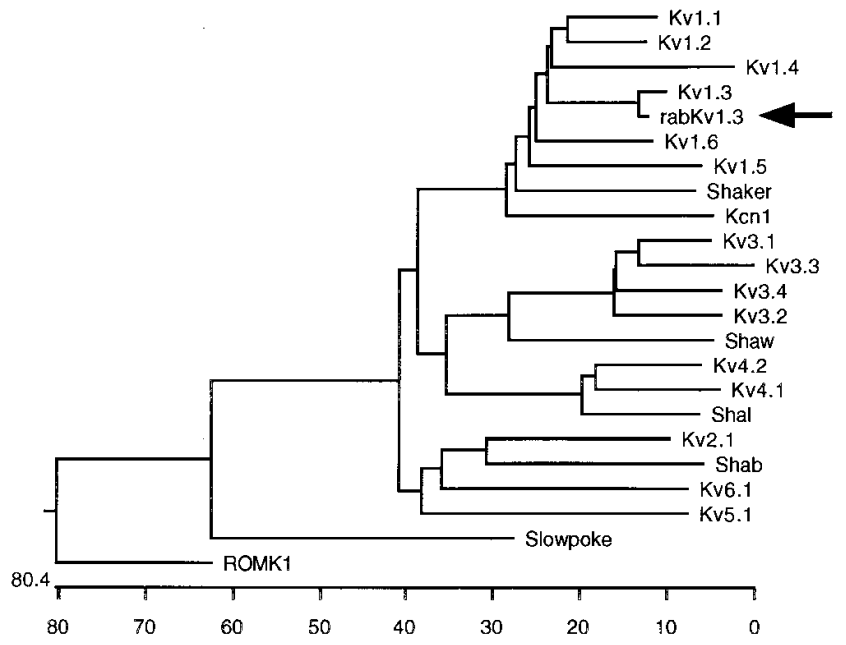

Figure 3. Phylogenetic tree analysis of $\mathrm{rabK}_{\mathrm{v1} 13}$. The length of each branch indicates the degree of divergence from an ancestral node as described in Methods. rabK $\mathrm{K}_{\mathrm{v} 1.3}$ is indicated by the arrow. $\mathrm{K}_{\mathrm{v} 1}-\mathrm{K}_{\mathrm{v} 6}$ represent prototypical members of the Shaker subfamily. Shaw, Shab, and Shal represent the other known members of the Shaker superfamily. Kcn1, cGMP-gated K channel (26). The GenBank accession numbers for the sequences used are: $\mathrm{K}_{\mathrm{v} 1.1}, \mathrm{M} 30439 ; \mathrm{K}_{\mathrm{v1} .2}, \mathrm{M} 30440$; $\mathrm{K}_{\mathrm{v} 1.3}, \mathrm{M} 30441 ; \mathrm{K}_{\mathrm{v} 1.4}, \mathrm{X} 16002 ; \mathrm{K}_{\mathrm{v} 1.5}, \mathrm{M} 27158 ; \mathrm{K}_{\mathrm{v} 1.6}, \mathrm{M} 96688 ;$ Shaker, M17211; Shaw, M32661; Shab, M64228; Shal, S64320; K $\mathrm{cn1}$, U38182; $\mathrm{K}_{\mathrm{v} 3.1}, \mathrm{M} 68880 ; \mathrm{K}_{\mathrm{v} 3.3}, \mathrm{Z} 11585 ; \mathrm{K}_{\mathrm{v} 3.4}, \mathrm{M} 81253 ; \mathrm{K}_{\mathrm{v} 3.2}, \mathrm{M} 59211 ; \mathrm{K}_{\mathrm{v} 4.2}$, M59980; $\mathrm{K}_{\mathrm{v} 4.1}, \mathrm{M} 64226 ; \mathrm{K}_{\mathrm{v} 2.1}, \mathrm{~L} 02840 ; \mathrm{K}_{\mathrm{v} 6.1}, \mathrm{M} 81784 ; \mathrm{K}_{\mathrm{v} 5.1}, \mathrm{M} 81783$; Slowpoke, L16912; Romk1, X72341. 


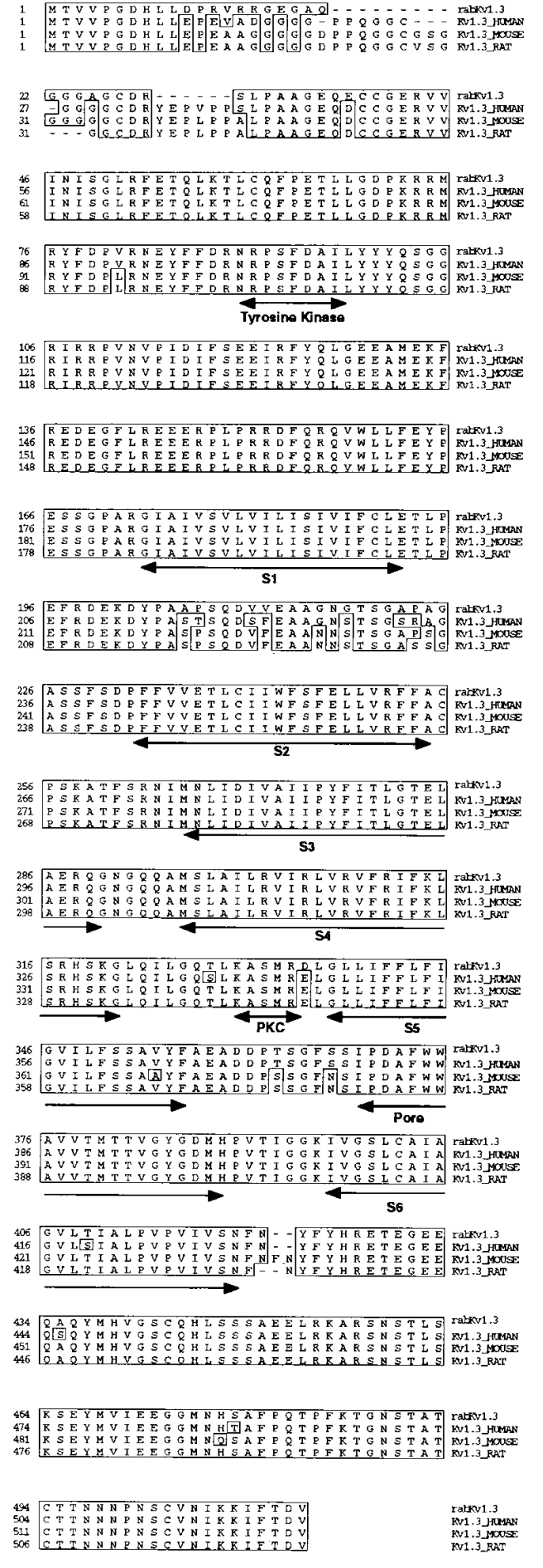

Figure 4. Deduced amino acid translation of $\mathrm{rabK}_{\mathrm{v} 1.3}$ compared with human, mouse, and rat $\mathrm{K}_{\mathrm{v} 1.3}$ gene families. The computer program Align (DNASTAR) was used to align the sequences. Areas of perfect alignment lie within the boxed regions. Putative transmembrane segments (S1-S6), pore region, and a tyrosine kinase site are marked beneath the alignment. A putative PKC site is indicated.

Expression of cloned rabK $\mathrm{K}_{v 1.3}$ in Xenopus oocytes. In oocytes injected with $5 \mathrm{ng}$ of $\mathrm{rabK}_{\mathrm{v} 1.3}$ capped RNA, voltage steps from -80 to $+80 \mathrm{mV}$ from a holding potential of $-80 \mathrm{mV}$ elicited the currents shown in Fig. 6. Outward current was observed
Table I. Sequence Comparison for $K_{v 1.3}$ Genes Isolated from Different Species

\begin{tabular}{|c|c|c|c|}
\hline & Human & Mouse & Rat \\
\hline \multicolumn{4}{|c|}{ Complete deduced amino acid sequence } \\
\hline Rabbit & 93.8 & 90.9 & 91.3 \\
\hline Human & & 89.8 & 90.8 \\
\hline Mouse & & & 94.9 \\
\hline \multicolumn{4}{|c|}{ Amino terminus } \\
\hline Rabbit & 60 & 57.5 & 52.5 \\
\hline Human & & 80 & 80 \\
\hline Mouse & & & 92.3 \\
\hline \multicolumn{4}{|c|}{ Nucleotide sequence of coding region } \\
\hline Rabbit & 90.1 & 84.9 & 84.9 \\
\hline Human & & 82.6 & 88.7 \\
\hline Mouse & & & 95.2 \\
\hline \multicolumn{4}{|c|}{$5^{\prime}$ coding region } \\
\hline Rabbit & 69.2 & 60 & 64.2 \\
\hline Human & & 80 & 78 \\
\hline Mouse & & & 91.7 \\
\hline
\end{tabular}

Amino acid similarity between rabbit, human, mouse, and rat $\mathrm{K}_{\mathrm{V} 1.3}$ proteins was determined using the Clustal method with a PAM250 residue weight table. Nucleotide similarity was measured using the Clustal method with a weighted residue weight table. The amino terminus $\left(5^{\prime}\right.$ coding region) used for comparison consisted of the first 40 amino acids (aa) of the rabbit protein and the corresponding regions in human (aa $1-50$ ), mouse (aa 1-55), and rat (aa 1-52).

only at test potentials more positive than -20 to $-30 \mathrm{mV}$. Peak outward current increased with more positive voltages. Peak current at $+60 \mathrm{mV}$ was $0.75 \pm 0.12 \mu \mathrm{A}(n=27)$. To estimate the selectivity of rabK $_{\mathrm{v} 1.3}$ with respect to potassium, rubidium, and sodium, tail currents were examined at voltages ranging from -100 to $+20 \mathrm{mV}$. A representative experiment is shown in Fig. 7, $A$ and $B$, where tail currents were measured when external $[\mathrm{K}]$ or $[\mathrm{Rb}]$ was increased from 10 to $88 \mathrm{mM}$. Changes in reversal potentials were plotted against changes in $\mathrm{K}$ and $\mathrm{Rb}$ concentrations. The zero-current conductance ratios for $\mathrm{K}: \mathrm{Na}$ and $\mathrm{Rb}: \mathrm{Na}$ were calculated based on the observed change in reversal potential per decade change in external cation concentration: $\mathrm{P}_{\mathrm{K}}: \mathrm{P}_{\mathrm{Na}}=35.5$ and $\mathrm{P}_{\mathrm{Rb}}: \mathrm{P}_{\mathrm{Na}}=12$. Substituting gluconate for chloride did not change the magnitude of the outward current. These results indicate that rabK $\mathrm{v}_{\mathrm{v} .3}$ expresses a highly selective voltage-gated $\mathrm{K}$ channel that is also permeable to $\mathrm{Rb}$.

The time constants of activation $\left(\tau_{\text {act }}\right)$ and inactivation $\left(\tau_{\text {inact }}\right)$ were determined using single-step command voltage protocols (voltage steps from -60 to $+80 \mathrm{mV}$ from a holding potential of $-80 \mathrm{mV}$ ). The currents were fitted to an empirical equation of the Hodgkin-Huxley model using the Pulse-Fit program (Heka). Based on these fits, the calculated values for $\tau_{\text {act }}$ and $\tau_{\text {inact }}$ (Fig. 8) are similar to those reported for other cloned Shaker $\mathrm{K}$ channels. $\mathrm{K}_{\mathrm{V} 1.3-\mathrm{GLIB}}$ activation and inactivation are voltage dependent, i.e., accelerated by depolarization. When plotted against command voltage, the $\tau_{\text {act }}$ and $\tau_{\text {inact }}$ values were each best fitted with a double exponential indicating a highly voltage-sensitive component and less voltage-sensitive component. Near $-10 \mathrm{mV}$, the time constant of voltage-depen- 
A
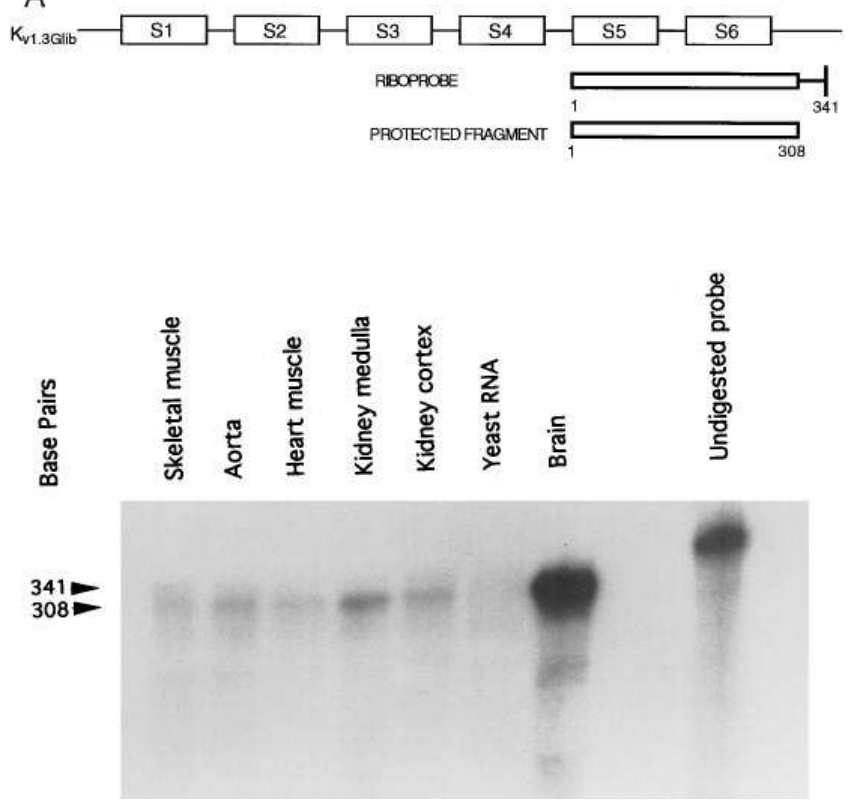

dent activation decreases sharply ( $e$-fold for every $0.5 \mathrm{mV}$ depolarization), whereas at more depolarizing potentials the time constant of activation shortens $e$-fold for every $21.5-\mathrm{mV}$ increment $\left(\Psi_{1 \text {-act }}=0.5 \mathrm{mV}, \Psi_{\text {2-act }}=21.5 \mathrm{mV}\right)$. Similarly, near $+10 \mathrm{mV}$, the time constant of voltage-dependent inactivation decreases sharply ( $e$-fold for every $3.3 \mathrm{mV}$ depolarization), whereas at more depolarizing potentials the time constant of inactivation shortens $e$-fold for every $20.7 \mathrm{mV}$ increment $\left(\Psi_{1 \text {-inact }}=3.3 \mathrm{mV}, \Psi_{2 \text {-inact }}=20.7 \mathrm{mV}\right)$.

The inhibitor profile (Table II) of rabK $_{\mathrm{v} 1.3}$ with regard to CTX, TEA, barium, and 4 amino-pyridine (4-AP) is similar to that of previously cloned and characterized $\mathrm{K}_{\mathrm{v} 1.3}$ channel proteins (19). A novel finding is that $\mathrm{rabK}_{\mathrm{v} 1.3}$ is sensitive to inhibition by the sulfonylurea drug glibenclamide (Fig. 9). Zhou et al. (20) observed that the glibenclamide sensitivity (at a dose
Figure 5. Differential expression of rabK $_{\mathrm{v} 1.3}$ in rabbit. $(A)$ Location of riboprobe in the coding region of $\mathrm{rabK}_{\mathrm{v} 1.3}$ and the sizes of both the riboprobe and protected fragment. RPAs were carried out as described in Methods. The tissues tested are shown on top. $100 \mu \mathrm{g}$ of RNA was used in each reaction. As a control, the probe was also hybridized to $100 \mu \mathrm{g}$ of yeast tRNA. The bands represent protected fragments and their intensity indicates relative transcript abundance. $(B)$ rabK $_{\mathrm{v} 1.3}$ is expressed in the rabbit inner medullary cell line GRB-PAP1: cDNA was synthesized from GRB-PAP1 total RNA using an antisense, rabK $_{\mathrm{v} 1.3}$ specific primer. PCR was then carried out as described in Methods. Lane 1 is negative control; lanes 2 and 3 are 1 and $2 \mu l$ cDNA, respectively. The PCR products were transferred to GeneScreen and probed with an internal, rabK $_{\mathrm{v} 1.3}$ specific primer. The expected product size is 958 base pairs.

of $100 \mu \mathrm{M}$ ) for the ROMK2 channel varied for different batches of oocytes. This finding has not been reported by others and in the course of our studies (30 oocytes from eight different frogs) we have noted invariably an inhibitory effect of glibenclamide at $100 \mu \mathrm{M}$. Glibenclamide begins to inhibit channel activity within 2 min after it is added to the bath. A $\mathrm{K}_{\text {ATP }}$ channel and a glibenclamide-sensitive $\mathrm{K}_{\mathrm{v}}$ channel have been observed in the same tissue from rabbit. Beech et al. (21) found both conductances in smooth muscle cells from rabbit portal vein. The $\mathrm{K}_{\mathrm{v}}$ conductance they observed is consistent with $\mathrm{K}_{\mathrm{v} 1.2}$ or $\mathrm{K}_{\mathrm{v} 1.3}$. The whole-cell $\mathrm{K}_{\mathrm{v}}$ conductance was sensitive to glibenclamide with an $\mathrm{IC}_{50}$ of $\sim 100 \mu \mathrm{M}$, while the $\mathrm{K}_{\mathrm{ATP}}$ channel was $>500$ times more sensitive with an $\mathrm{IC}_{50}$ of $\sim 200$ $\mathrm{nM}$. Thus, the glibenclamide sensitivity of $\operatorname{rabK}_{\mathrm{v} 1.3}$ is on the order of that for the native channel in vascular smooth muscle.
A

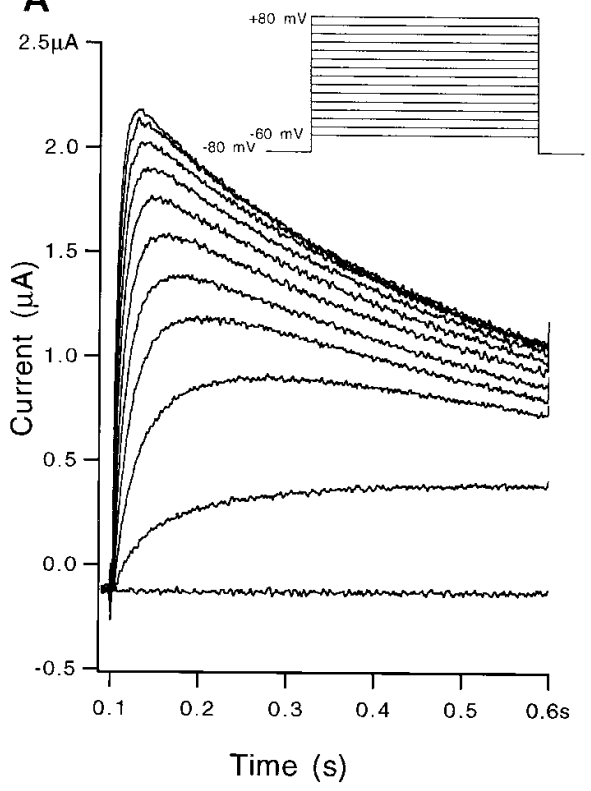

B

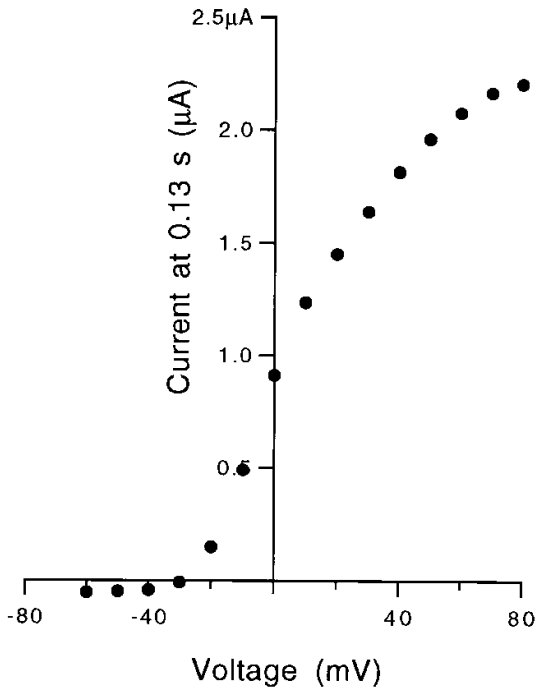

Figure 6. rabK $_{\mathrm{v} 1.3}$ expresses a voltage-gated, potassium channel in Xenopus oocytes. Oocytes were injected with $5 \mathrm{ng}$ rabK $_{\mathrm{v} 1.3}$ RNA. Oocytes were bathed in solution containing (mM): $88 \mathrm{KCl}, 2 \mathrm{NaCl}, 1 \mathrm{CaCl}_{2}, 1 \mathrm{MgCl}_{2}, 2.5$ $\mathrm{NaH}_{2} \mathrm{CO}_{3}, 5$ Hepes, pH 7.4. (A) Current records elicited by applying voltage steps from -60 to $+80 \mathrm{mV}$ in $10 \mathrm{mV}$ increments from a holding potential of $-80 \mathrm{mV}$. (B) Current-voltage relation at $0.13 \mathrm{~s}$. 


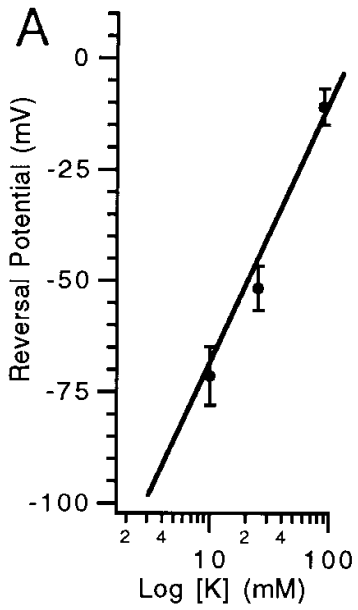

This drug is a well known inhibitor of ATP-sensitive K channels $\left(\mathrm{K}_{\mathrm{ATP}}\right)$. Pancreatic and cardiac $\mathrm{K}_{\mathrm{ATP}}$ channels have higher affinity for glibenclamide and their activity is inhibited, in vivo, by nanomolar concentrations of the drug. In contrast, inhibition of renal $\mathrm{K}_{\mathrm{ATP}}$ channels only occurs at significantly higher concentrations of glibenclamide $(10-500 \mu \mathrm{M})$. The molecular mechanism of $\mathrm{K}_{\mathrm{ATP}}$ inhibition by glibenclamide has been the subject of intense investigation largely because $\mathrm{K}_{\mathrm{ATP}}$ channels play an important role in a variety of processes such as insulin secretion and vasoregulation and because sulfonylurea drugs are widely used for the treatment of non-insulin-dependent diabetes mellitus. The newly cloned inward rectifier K channels (ROMK family) are prime candidates for being the molecular counterpart of $\mathrm{K}_{\mathrm{ATP}}$ channels. It has been postulated that in vivo the $\mathrm{K}_{\mathrm{ATP}}$ channel is a heteromultimeric complex and that glibenclamide binds to a separate subunit. A high affinity glibenclamide-binding protein was recently isolated from pancreatic $\beta$ cells (22). However, it appears that this protein is not itself a potassium channel, and when coexpressed with putative $\mathrm{K}_{\mathrm{ATP}}$ channel proteins it does not confer glibenclamide sensitivity to the cloned $\mathrm{K}$ channels. The deduced secondary structure of the high affinity glibenclamide receptor is similar to that of the CFTR protein (defective in cystic fibrosis). CFTR can function as a chloride channel and is inhibited by micromolar concentrations of glibenclamide. This finding provides support for the notion that an additional subunit similar in structure to the glibenclamide binding proteins ( $\beta$ cell sulfonylurea receptor and CFTR) is required for $\mathrm{K}$ channel inhibition
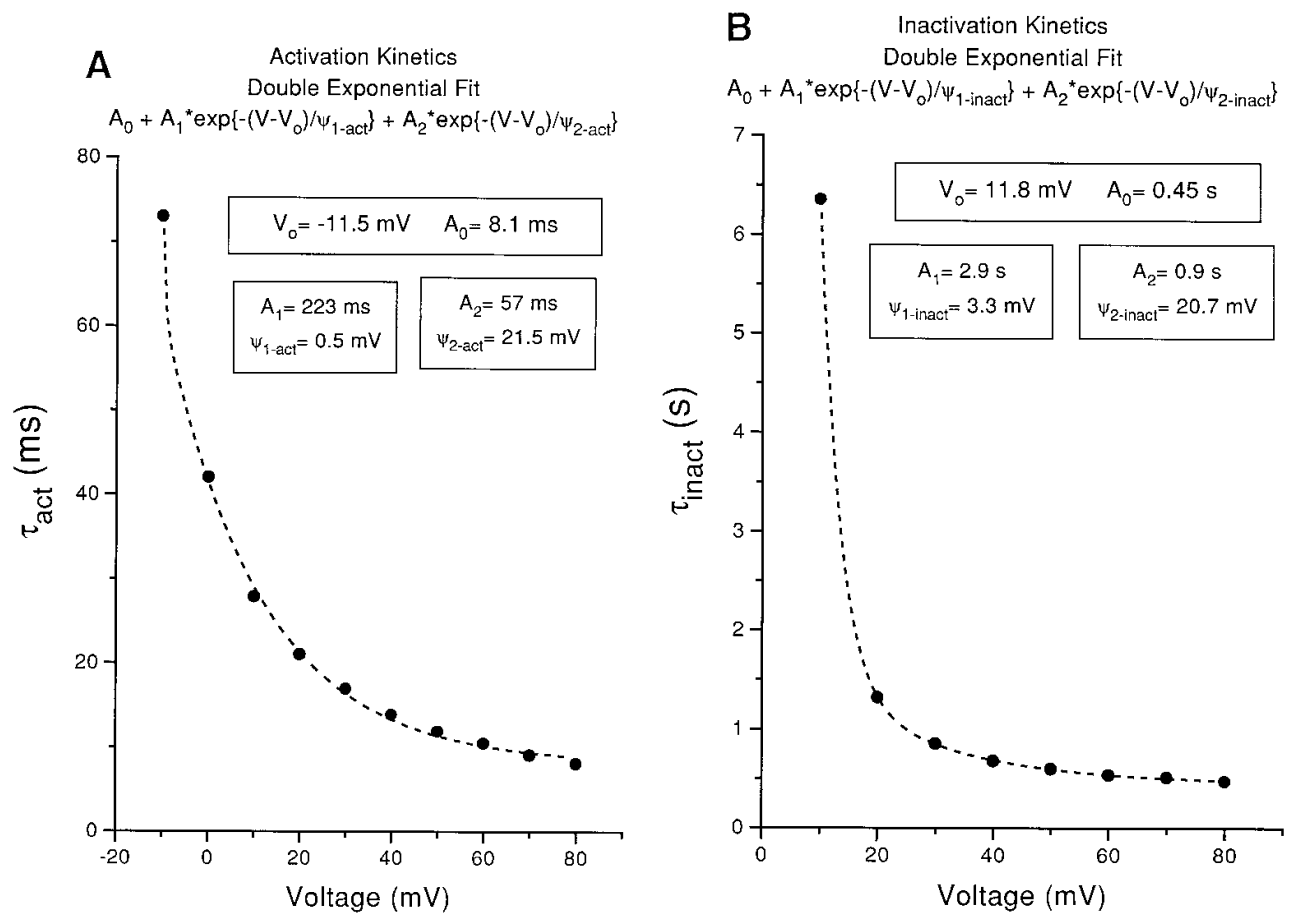

Figure 8. Kinetics of activation and inactivation of $\mathrm{rabK}_{\mathrm{v} 1.3}$ current. Current traces were elicited by a single-step command voltage protocol (voltage steps from -80 to $+80 \mathrm{mV}$ from a holding potential of $-80 \mathrm{mV}$ ). Activation parameters (fit of current traces elicited by voltage steps ranging from -10 to $+80 \mathrm{mV}$ ) and inactivation parameters (fit of currents traces that inactivated, voltage steps ranging from +10 to $+80 \mathrm{mV}$ ) were determined using the Pulse-Fit program (Heka). The observed currents were fitted to Hodgkin-Huxley equation according a Simplex optimization algorithm. The best fit, judged by visual inspection and by examination of the root mean square deviation between fit and data, was obtained when the number of activation $(m)$ and inactivation gates $(h)$ was set at 1 and 2 , respectively. The time constants of $(A)$ activation $\left(\tau_{\text {act }}\right)$ and $(B)$ inactivation $\left(\tau_{\text {inact }}\right)$ were determined from the fit and plotted against voltage. These data were in turn fitted as indicated in the figure. $\Psi_{1 \text {-act }}$ and $\Psi_{2 \text {-act }}$ are constants of activation, $\Psi_{1 \text {-inact }}$ and $\Psi_{2 \text {-inact }}$ are constants of inactivation; filled circles indicate data and the dotted lines indicate fit. 
Table II. Inhibitor Profile of rabK $K_{v 1.3}$ at $+60 \mathrm{mV}$

\begin{tabular}{ccccc}
\hline Inhibitor & $4 \mathrm{AP}(5 \mathrm{mM})$ & $\mathrm{CTX}(1 \mathrm{nM})$ & $\mathrm{TEA}(50 \mathrm{mM})$ & $\mathrm{Glib}(250 \mu \mathrm{M})$ \\
\hline Percent inhibition & $84 \pm 1$ & $66 \pm 1.2$ & $78 \pm 3$ & $50 \pm 2$ \\
& $n=4$ & $n=5$ & $n=3$ & $n=5$ \\
\hline
\end{tabular}

Oocytes injected with $5 \mathrm{ng} \mathrm{rabK}_{\mathrm{v} 1.3}$ RNA were bathed in solution containing (mM): $88 \mathrm{KCl}, 2 \mathrm{NaCl}, 1 \mathrm{CaCl}_{2}, 1 \mathrm{MgCl}_{2}, 2.5 \mathrm{NaH}_{2} \mathrm{CO}_{3}, 5$ Hepes, $\mathrm{pH} 7.4$, and the indicated concentration of inhibitor. Peak current was measured at $+60 \mathrm{mV}$ from a holding potential of $-80 \mathrm{mV}$. The same protocol was applied to 10 water-injected oocytes, the current was averaged $(0.15 \mu \mathrm{A})$ and subtracted from all currents measured in rabK $_{\mathrm{v} 1.3}$ injected oocytes. Glib, glibenclamide.

by the sulfonylurea drugs. However, this requirement may not be absolute since our data clearly indicate that $\mathrm{rabK}_{\mathrm{v} 1.3}$ expresses a $\mathrm{K}$ current with similar affinity for glibenclamide as renal $\mathrm{K}_{\mathrm{ATP}}$ studied in vivo. This finding strengthens the proposal put forward by Edwards et al. (23) that under some conditions, $\mathrm{K}$ current identified as $\mathrm{K}_{\mathrm{ATP}}$ may actually represent current mediated by an altered $\mathrm{K}_{\mathrm{v}}$ channel.

Voltage-activated, K selective single channel currents were observed in oocytes expressing $>1.5 \mu \mathrm{A}$ of current (determined by whole cell two-electrode voltage clamp) using the

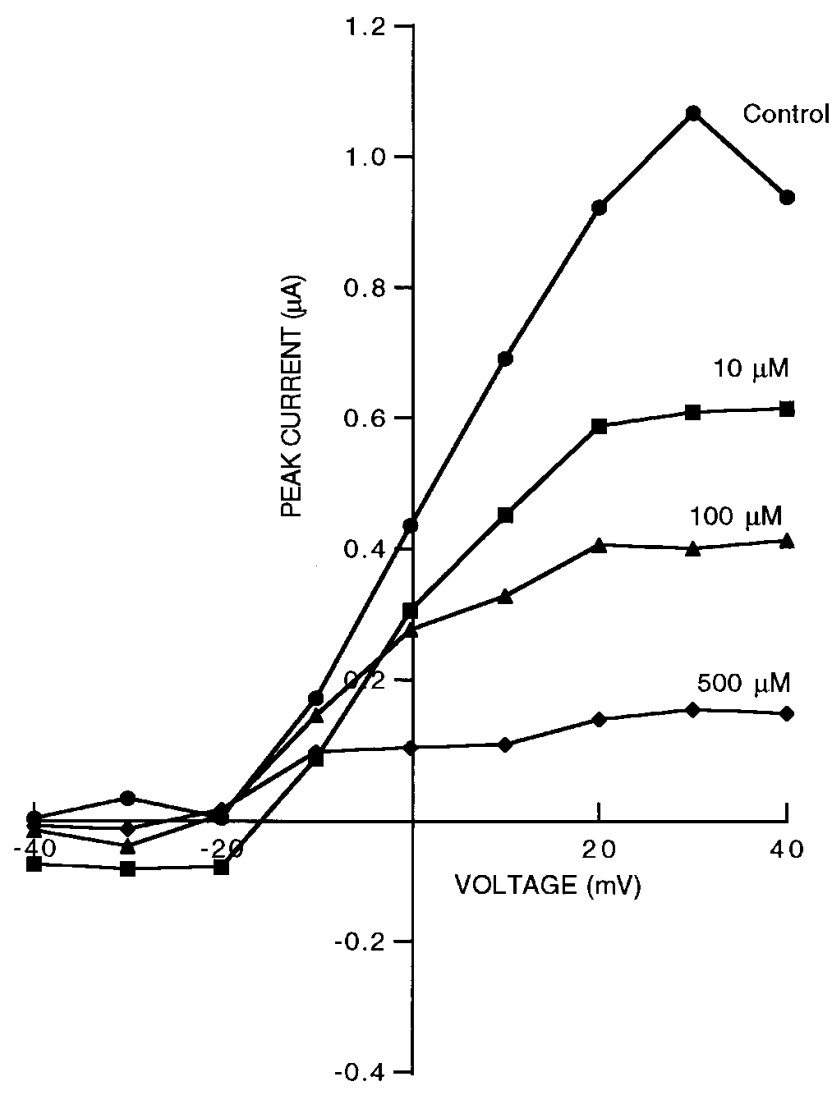

Figure 9. Inhibition of $\mathrm{rabK}_{\mathrm{v} 1.3}$ by glibenclamide. Oocytes injected with $5 \mathrm{ng} \mathrm{rabK} \mathrm{v}_{\mathrm{v} .3}$ RNA were bathed in solution containing (mM): 88 $\mathrm{KCl}, 2 \mathrm{NaCl}, 1 \mathrm{CaCl}_{2}, 1 \mathrm{MgCl}_{2}, 2.5 \mathrm{NaH}_{2} \mathrm{CO}_{3}, 5$ Hepes, $\mathrm{pH} 7.4$, and the indicated concentration of glibenclamide. Currents were elicited by applying voltage steps from -40 to $+40 \mathrm{mV}$ in $10 \mathrm{mV}$ increments from a holding potential of $-80 \mathrm{mV}$. Different symbols denote each [glibenclamide] as labeled. patch-clamp technique. Single channel activity is shown in Fig. 10. Examination of the transient response (Fig. $10 A$ ) upon pulsing from the holding potential of $-80 \mathrm{mV}$ to $0 \mathrm{mV}$ (the ensemble conductance goes through its maximum at $0 \mathrm{mV}$ ) shows that the channels are maximally active at the instant of depolarization, and that most of the inactivation occurs within 1,000 ms. Beyond that, there are occasional channel openings, but at a much lower open probability than during the transient. Representative steady state single channel records and I-V plot are shown in Fig. 10, $B$ and $C$. The single channel conductance of $\mathrm{rabK}_{\mathrm{v} 1.3}$ is $\sim 7 \mathrm{pS}(n=3)$. The channel is voltage activated, and outward current could be detected at depolarizations beginning at $-40 \mathrm{mV} .5 \mathrm{mM}$ 4-AP inhibits channel currents to the same extent as seen in the whole cell $(85 \pm 2 \%$, $n=3)$. The outward current through rabK $_{\mathrm{v} 1.3}$ upon stepping from -80 to $+60 \mathrm{mV}$ is not sensitive to ATP at a dose of $5 \mathrm{mM}$ applied to the cytoplasmic side of the membrane patch $(n=2)$. The single channel I-V plot is not linear, suggesting that rabK $_{\mathrm{v} 1.3}$ exhibits outward saturation. Although a similar observation has previously been reported for the Raw, a member of $\mathrm{K}_{\mathrm{v} 3}$ Shaker subfamily (24), this is the first demonstration that at least one member of the $\mathrm{K}_{\mathrm{v}}$ subfamily also exhibits outward saturation. In the Raw channel, saturation of the outward current appears to be due to blocking of the open channel by intracellular magnesium.

Possible physiological role of $K_{v 1.3}$ in kidney. To our knowledge, single channel data are not available on voltage-dependent $\mathrm{K}$ channels in native or cultured inner medullary collecting duct (IMCD)/papillary cells. Primary cultures of mouse IMCD cells have been studied by Light et al. (25), and although they found a cation nonselective channel in the apical membrane, they did not report any potassium-selective channels. Volk et al. (9) reported the existence of $\mathbf{K}_{\mathrm{v} 1.2}$ voltage-dependent channels in the GRB-PAP1 papillary cell line using whole-cell patch clamp. Since they did not report observing the $\mathrm{K}_{\mathrm{v} 1.2}$ channel in the apical cell-attached patch formed before going whole-cell, we presume the channel was not present in the apical membrane.

Given the available data, we propose that the $\mathrm{rabK}_{\mathrm{v} 1.3}$ channel is localized in the basolateral membrane of IMCD/papillary cells and functions in the reabsorption of potassium in this part of the nephron in low $\mathrm{K}$ states. The measured transepithelial voltage in this segment is 0 to $-2 \mathrm{mV}$ (lumen negative). Thus, paracellular $\mathrm{K}$ reabsorption would depend exclusively on a chemical gradient from lumen to interstitium. In our model we propose that transcellular passive $\mathrm{K}$ reabsorption occurs, and that rabK $_{\mathrm{v} 1.3}$ is involved in this process. These concepts have been incorporated into the model shown in Fig. 11.

When luminal $[\mathrm{K}]$ is high and luminal $[\mathrm{Na}]$ is low, $\mathrm{K}$ will enter the cell across apical cation nonselective cation channels. Low $\mathrm{Na}$ entry would reduce the relative turnover rate of the $\mathrm{Na}^{+}, \mathrm{K}^{+}$-ATPase pump, possibly depolarizing the basolateral membrane potential $\mathrm{V}_{\mathrm{bl}}$. As a result of low pump activity, intracellular ATP rises leading to closure of basolateral $\mathrm{K}_{\mathrm{ATP}}$ channels, further depolarizing $\mathrm{V}_{\mathrm{bl}}$ to a voltage determined by the conductances of other ions such as chloride. When the cell depolarizes beyond the threshold voltage $(\sim-40 \mathrm{mV})$, opening of the rabK $_{\mathrm{v} 1.3}$ channel would lead to outward $\mathrm{K}$ current and reabsorption. Because the reabsorbate remains trapped in the interstitium, the interstitial $\mathrm{K}$ concentration rises, further lowering the $\mathrm{V}_{\mathrm{bl}}$. On the other hand, opening rabK $_{\mathrm{v} 1.3}$ channels will tend to hold the basolateral membrane potential close to $\mathrm{E}_{\mathrm{K}}$. 

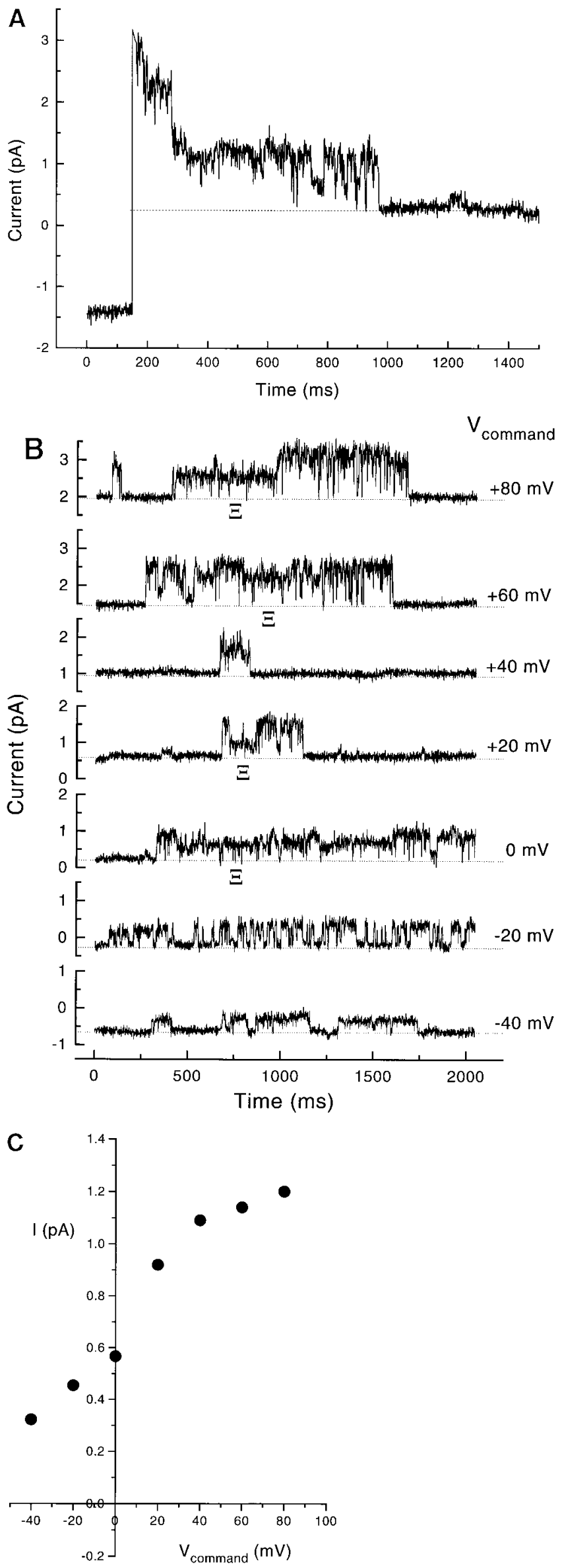

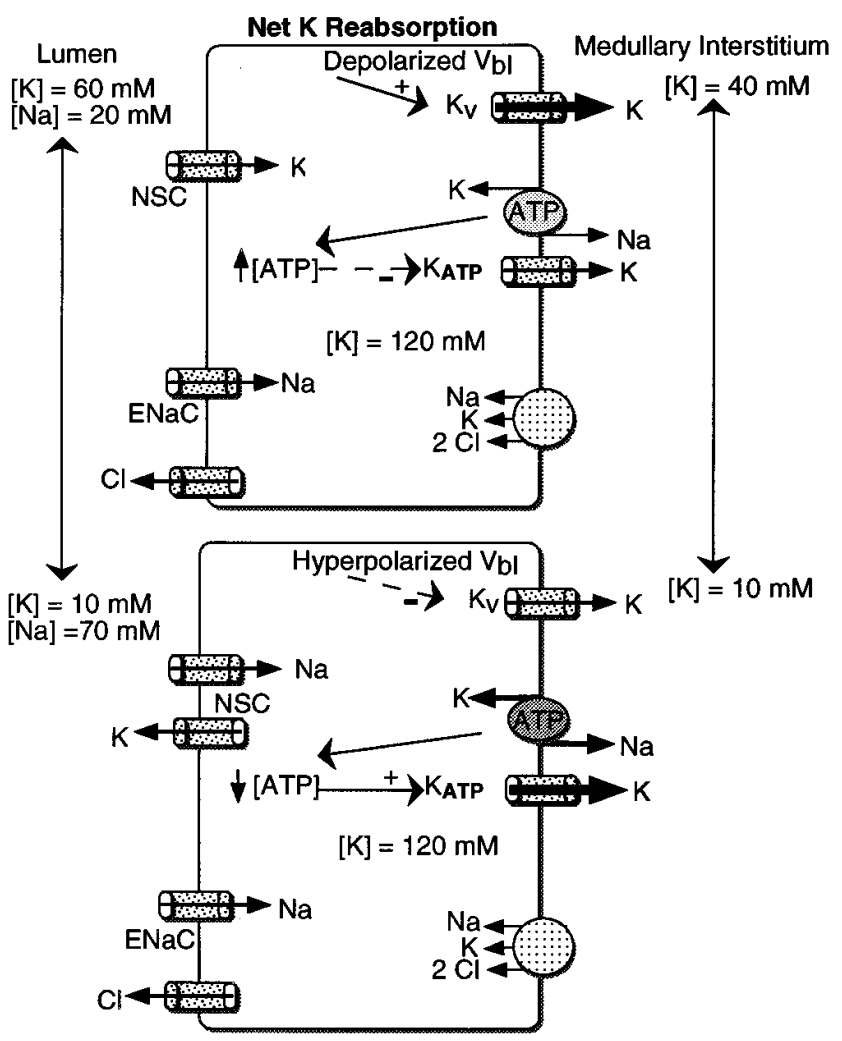

No Net K Reabsorption

Figure 11. Proposed physiological role of $\mathrm{rabK}_{\mathrm{v} 1.3}$ in the IMCD. See text for details. $\mathrm{V}_{\mathrm{bl}}$, basolateral membrane voltage; $N S C$, nonselective cation channel; $E N a C$, epithelial sodium channel; $\mathrm{K}_{\mathrm{v}}$, voltage-gated $\mathrm{K}$ channel; $\mathrm{K}_{\mathrm{ATP}}$, ATP-sensitive $\mathrm{K}$ channel.

When luminal $[\mathrm{K}]$ is low and $[\mathrm{Na}]$ high, apical sodium uptake will dominate. This depolarizes the apical membrane potential $\mathrm{V}_{\mathrm{a}}$ and stimulates the pump causing intracellular [ATP] to fall, allowing the basolateral $\mathrm{K}_{\mathrm{ATP}}$ channels to open. Stimulation of the pump will decrease interstitial $[\mathrm{K}]$ and hyperpolarize the basolateral membrane. When $\mathrm{V}_{\mathrm{bl}}$ becomes more negative than the threshold voltage of the rabK $\mathrm{v}_{\mathrm{v1.3}}$ channels, they close.

Thus the presence of two $\mathrm{K}$ channels on the basolateral membrane, each with different properties and regulation, would add robust flexibility to the system at sites distal to the outer medulla. When the IMCD is primarily absorbing sodium, the other voltage-independent, ATP-sensitive $\mathrm{K}_{\mathrm{ATP}}$ channels function in $\mathrm{K}$ recycling across the basolateral membrane. On the other hand, when the IMCD is primarily reab-

Figure 10. Single channel activity. (A) Transient response of rabK $\mathrm{v}_{\mathrm{v} 1.3}$ recorded from an inside-out patch excised in a bath containing 88 $\mathrm{mM} \mathrm{K}^{+}$(pipette $2 \mathrm{mM} \mathrm{K}^{+}$). In this case, upon depolarization to $0 \mathrm{mV}$ from the holding potential of $-80 \mathrm{mV}$, at least three channels open and subsequently inactivate within $1 \mathrm{~s}$. The dashed line indicates the closed current level at $0 \mathrm{mV}$. The seal resistance of this membrane patch is at least $48.5 \Omega$. (B) Steady state single channel tracings for rabK $_{\mathrm{v} 1.3}$. Single channels recorded from an inside-out membrane patch from oocytes injected with $5 \mathrm{ng} \mathrm{rabK}_{\mathrm{v} 1.3}$ RNA. Pipette: $\mathrm{NaCl}$, Bath: $\mathrm{KCl}$. $\Xi$ denotes a probable subconductance level. (C) I-V plot for the major conductance level in the same patch. 
sorbing potassium, the ATP-insensitive, voltage-gated rabK $_{\mathrm{v} 1.3}$ channels mediate the exit step across the basolateral membrane.

We conclude that rabK $\mathrm{v} 1.3_{3}$ is a novel member of the $\mathrm{K}_{\mathrm{v} 1.3}$ Shaker subfamily that is expressed in kidney medulla and in the renal medullary cell line GRB-PAP1. Although rabK $_{\mathrm{v} 1.3}$ is a voltage-gated $\mathrm{K}$ channel with kinetic properties similar to those of other previously cloned $\mathrm{K}_{\mathrm{v} 1.3}$ channels, it exhibits two properties hitherto unreported: inhibition by glibenclamide and outward saturation of single channel current. The identification of rabK $_{\mathrm{v} 1.3}$ expands our knowledge of the types of voltage-gated $\mathrm{K}$ channels expressed in kidney and supports the notion that such channels play an important role in renal $\mathrm{K}$ homeostasis.

\section{Acknowledgments}

G.V. Desir received Career Development and Merit Review awards from the Veterans Administration and National Institutes of Health grant DK-48105B and is an Established Investigator of the American Heart Association.

\section{References}

1. Catterall, W., and P.N. Epstein. 1992. Ion channels. Diabetologia. 35(Suppl. 2):S23-S33.

2. Rusch, N.J., and W.J. Stekiel. 1991. Ionic channels of vascular smooth muscle in hypertension. Adv. Exp. Med. Biol. 308:1-7.

3. Siegel, G., J. Emden, K. Wenzel, J. Mironneau, and G. Stock. 1992. Potassium channel activation in vascular smooth muscle. Adv. Exp. Med. Biol. 311:53-72.

4. Bolotina, V.M., S. Najibi, J.J. Palacino, P.J. Pagano, and R.A. Cohen. 1994. Nitric oxide directly activates calcium-dependent potassium channels in vascular smooth muscle. Nature (Lond.). 368:850-856.

5. Rae, J.L. 1993. Ion channels in ocular epithelia. Invest. Ophthalmol. \& Visual. Sci. 34:2608-2612.

6. DeCoursey, T.E., E.R. Jacobs, and M.R. Silver. 1988. Potassium currents in rat type II alveolar epithelial cells. J. Physiol. (Lond.). 395:487-505.

7. Hunter, M., A.G. Lopes, E. Boulpaep, and G. Giebisch. 1986. Regulation of single $\mathrm{K}$ channels from apical membranes of rabbit collecting tubules. Am. J. Physiol. 25:F725-F733.

8. Jamison, R.L., J. Work, and J.A. Schafer. 1982. New pathways for potassium transport in the kidney. Am. J. Physiol. 242:F297-F312.

9. Volk, K.A., R.F. Husted, C.J. Pruchno, and J.B. Stokes. 1994. Functional and molecular evidence for Shaker-like $\mathrm{K}^{+}$channels in rabbit renal papillary epithelial cell line. Am. J. Physiol. (Renal, Fluid Electrolyte Physiol.). 267:F671-F678.
10. Desir, G.V., and H. Velazquez. 1993. Identification of a novel K-channel gene (KC22) that is highly expressed in distal tubule of rabbit kidney. Am. J. Physiol. 264:F128-F133.

11. Sanger, F., S. Nicklen, and A.R. Coulson. 1977. DNA sequencing with chain-terminating inhibitors. Proc. Natl. Acad. Sci. USA. 74:560-564.

12. Higgins, D.G., A.J. Bleasbly, and R. Fuchs. 1992. CLUSTALV: improved software for multiple sequence alignment. CABIOS. 8:189-191.

13. Sharp, P.A., A.J. Berk, and S.M. Berget. 1980. Transcription maps of adenovirus. Methods Enzymol. 65:750-768.

14. Ahmad, I., C. Korbmacher, A.S. Segal, P. Cheung, E.L. Boulpaep, and C.J. Barnstable. 1992. Mouse cortical collecting duct cells show nonselective cation channel activity and express a gene related to the cGMP-gated rod photoreceptor channel. Proc. Natl. Acad. Sci. USA. 89:10262-10266.

15. Chandy, G.K., and G.A. Gutman. 1995. Voltage-gated potassium channel genes. In Handbook of Receptors and Channels. A.R. North, editor. CRC Press, Inc., Boca Raton, FL. 1-71.

16. Hopkins, W.F., V. Demas, and B.L. Tempel. 1994. Both N- and C-terminal regions contribute to the assembly and functional expression of homo- and heteromultimeric voltage-gated $\mathrm{K}^{+}$channels. J. Neurosci. 14:1385-1393.

17. Lee, T.E., L.H. Philipson, A. Kuznetsov, and D.J. Nelson. 1994. Structural determinant for assembly of mammalian $\mathrm{K}^{+}$channels. Biophys. J. 66:667673 .

18. Stuhmer, W., J.P. Ruppersberg, K.H. Schroter, B. Sakmann, M. Stocker, K.P. Giese, A. Perschke, A. Baumann, and O. Pongs. 1989. Molecular basis of functional diversity of voltage-gated potassium channels in mammalian brain. EMBO (Eur. Mol. Biol. Organ.) J. 8:3235-3244.

19. Hsu, Y.-T., and R.S. Molday. 1993. Modulation of the cGMP-gated channel of rod photoreceptor cells by calmodulin. Nature (Lond.). 361:76-79.

20. Zhou, H., S.S. Tate, and L.G. Palmer. 1994. Primary structure and functional properties of an epithelial K channel. Am. J. Physiol. (Cell Physiol.). 266: C809-C824.

21. Beech, D.J., H. Zhang, K. Nakao, and T.B. Bolton. 1993. Single channel and whole-cell K-currents evoked by leucromakalin in smooth muscle cells from the rabbit portal vein. Br. J. Pharmacol. 110:583-590.

22. Aguilar-Bryan, L., C.G. Nichols, S.W. Wechsler, J.P. Clement IV, A.E. Boyd III, G. Gonzalez, H. Herrera-Sosa, K. Nguy, J. Bryan, and D.A. Nelson. 1995. Cloning of the $\beta$ cell high-affinity sulfonylurea receptor: a regulator of insulin secretion. Science (Wash. DC). 268:423-426.

23. Edwards, G., and A.H. Weston. 1994. KATP - fact or artefact? New thoughts on the mode of action of the potassium channel openers. Cardiovasc. Res. 28:735-741.

24. Rettig, J., F. Wunder, M. Stocker, R. Lichtinghagen, F. Mastiaux, S Beckh, W. Kues, P. Pedarzani, K.H. Schröter, J.P. Ruppersberg, et al. 1992. Characterization of a Shaw-related potassium channel family in rat brain. EMBO (Eur. Mol. Biol. Organ.) J. 11:2473-2486.

25. Light, D.B., E.M. Schwiebert, K.H. Karlson, and B.A. Stanton. 1989. Atrial natriuretic peptide inhibits a cation channel in renal inner medullary collecting duct cells. Science (Wash. DC). 243:383-385.

26. Yao, X., A.S. Segal, P. Welling, Z. Zhang, C.M. McNicholas, D. Engel, E.L. Boulpaep, and G.V. Desir. 1995. Primary structure and functional expression of a cGMP-gated potassium channel. Proc. Natl. Acad. Sci. USA. 92:1171111715. 